\title{
Margaret McCartney: Glasgow's lost hospital beds
} (a) $\mathbb{( 1 ) \Theta}$ OPEN ACCESS

\author{
Margaret McCartney, general practitioner
}

Glasgow

I've been to several meetings about the big new hospital being built in my home town. It was to be called the Southern Glasgow University NHS Trust. But then Liz visited, and it was renamed the Queen Elizabeth University Hospital. Colloquially, it's still being called the Death Star.

It's enormous, dwarfing its hospital contemporaries and glowing bright at all hours, with a helipad on the roof. It has separate bedrooms for all patients.

I raised basic questions at the meetings.

Where was the evidence that single rooms were safe? Not answered.

How many beds would be lost as a result of the shift from the old Western Infirmary to the shiny new Southern? No one could tell me. Some. Many. Quite a few. Not yet decided.

A few months ago, on an ordinary working day with no seasonal flu, patients were being diverted to the Glasgow Royal Infirmary because the Southern had run out of beds. Many people have told me much the same about day to day working: jam packed, overflowing with people whose needs couldn't be met despite the huge efforts of staff.

I asked the hospital's press office how many beds had been lost in the reconfiguration. It suggested that I make a request under freedom of information legislation. But I work here: Southern is my local hospital, and it's bizarre to have to resort to the law to get this information.

Here is the result of my request: in 2011 Glasgow had 3077 acute inpatient beds; now it has 2812. In 2011 Glasgow and Clyde had 471 continuing care and disability beds; now it has 372.

I've been told that we shouldn't worry about this loss of beds because there is and will be more care in the community and because merging social care with healthcare will mean better integration, where more can be done with less.

But what's the reality? Cuts to council budgets have been brutal throughout the United Kingdom. Despite much talk of protecting front line services Glasgow's council spending on third sector organisations, especially those related to mental healthcare, has been cut.

Council staff report high levels of stress, and it's clear that they, as well as healthcare professionals, are having to deal with people in more complex situations. ${ }^{1}$ People are ageing with multimorbidity and increasing care needs. Resources haven't been transferred to pay for the necessary rise in numbers of district nurses: they're phenomenally busy, delivering insulin twice a day and dressings daily, making multiple visits each day to dying people, and keeping legions safely out of hospital. Until we allocate funds for health and social care properly, the deficit will make itself known in crowded emergency departments and in GPs' waiting rooms.

Resources haven't been transferred to pay for the necessary rise in numbers of district nurses: they're phenomenally busy, keeping legions safely out of hospital

Competing interests: See www.bmj.com/about-bmj/freelancecontributors/margaret-mccartney.

Provenance and peer review: Commissioned; not externally peer reviewed.

Follow Margaret on Twitter, @mgtmccartney

1 Scotland ISDN. Weekly update of emergency department activity and waiting times statistics. 19 Jan 2016. www.isdscotland.org/Health-Topics/Emergency-Care/Publications/ data-tables. . asp? $\mathrm{id}=1580 \# 1580$.

Published by the BMJ Publishing Group Limited. For permission to use (where not already granted under a licence) please go to http://group.bmj.com/group/rights-licensing/ permissions

This is an Open Access article distributed in accordance with the Creative Commons Attribution Non Commercial (CC BY-NC 3.0) license, which permits others to distribute, remix, adapt, build upon this work non-commercially, and license their derivative works on different terms, provided the original work is properly cited and the use is non-commercial. See: http://creativecommons.org/licenses/by-nc/3.0/. 